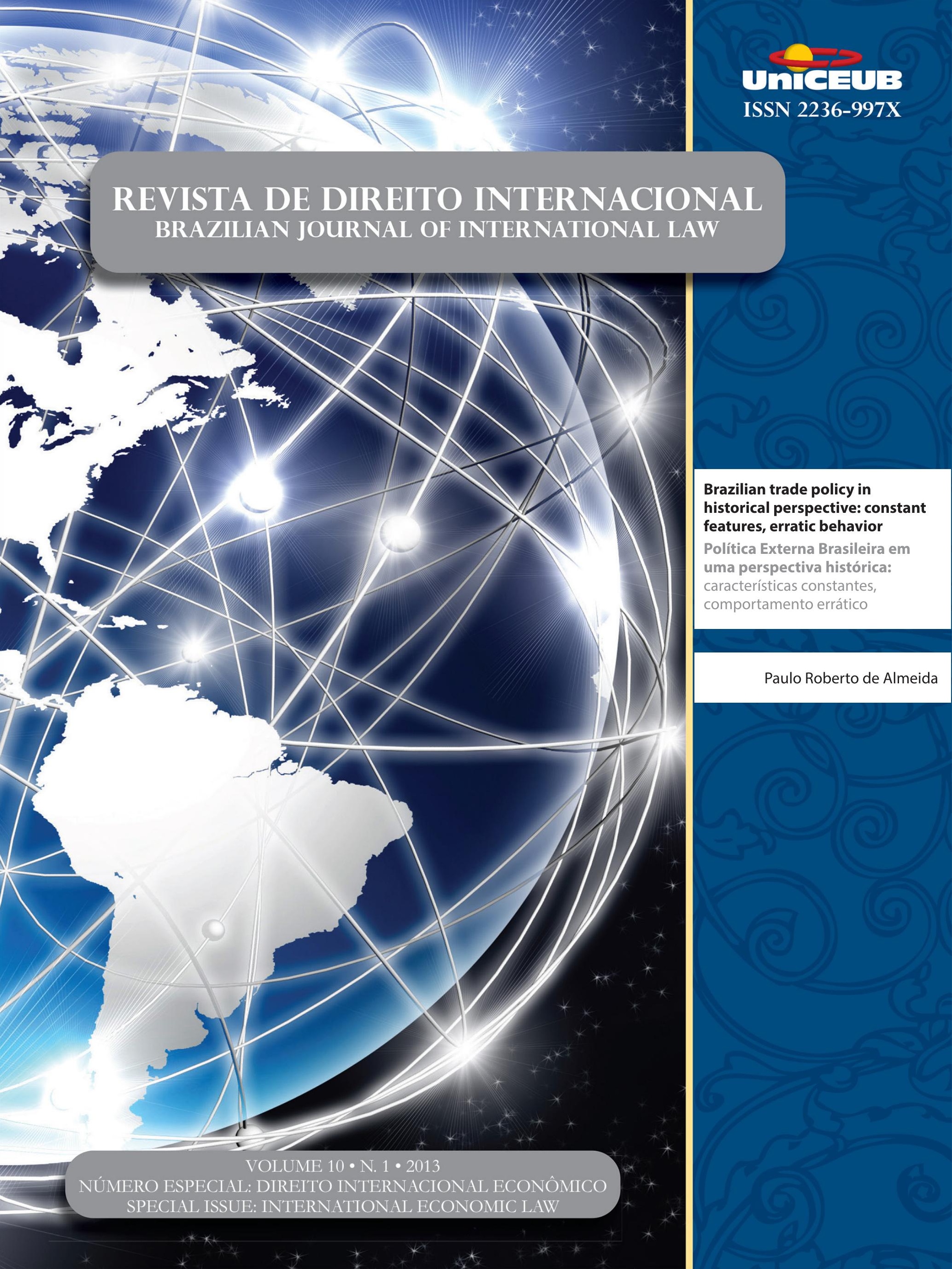


Crônicas de direito internacional ............................................................. Julia Motte-Baumvol e Alice Rocha da Silva

BRAZILIAN TRADE POLICY IN HISTORICAL PERSPECTIVE: CONSTANT FEATURES, ERRATIC BEHAVIOR..11 Paulo Roberto de Almeida

Aspectos GEopolíticos do GAT'T E DA OMC .........................................................28 José Fontoura Costa

A REgulaÇÃo INTERNACIONAL dos SUbSídios AGRÍCOLAS: A CONTEMPORANEIDADE DO PARADIGMA REALISTA PARA A COMPREENSÃO DO SISTEMA DE COMÉRCIO AGRÍCOLA INTERNACIONAL VIGENTE

Natália Fernanda Gomes

ACORDO TRIPS: ONE-SIZE-FITS-ALL?

Tatianna Mello Pereira da Silva

É INTERESSANTE PARA O BRASIL ADERIR AO ACORDO SOBRE COMPRAS GOVERNAMENTAIS DA OMC?

Clarissa Chagas Sanches Monassa e Aubrey de Oliveira Leonelli

A Defesa COMERCIAL E A RESTRIÇÃo dA LIBERALIZAÇÃo E DA INTEGRAÇÃo COMERCIAL PELO AUMENTO DA ALÍQUOTA DE IPI DE VEÍCULOS IMPORTADOS NO BRASIL...................................86

Ricardo Serrano Osorio e Clayton Couto

A COOPERAÇÃo INTERNACIONAL NA DEFESA DA CONCORRÊNCIA

Vinicius Marques de Carvalho e Paulo Burnier da Silveira

Os ACORDOS DE COMÉRCIO PARA ALÉM DAS PREFERÊNCIAS: UMA ANÁLISE DA REGULAMENTAÇÃO SOBRE OS "NOVOS TEMAS" 105

Michelle Ratton Sanchez Badin e Lucas da Silva Tasquetto

INTEGRAÇÃO ECONÔMICA NO MERCOSUL: OPINIÕES CONSULTIVAS E A DEMOCRATIZAÇÃO NO ACESSO AO TRIBUNAL PERMANTE DE REVISÃO 128 Eduardo Biachi Gomes

"Fundos abutres" vs. Estados NaCionais: SObERANiA E ATUAÇÃo do Tribunal INTERNACIONAL do Direito do Mar a partir do Caso da Fragata libertad.. 138 Alexandre Pereira da Silva e Mariana Yante Barrêto Pereira

INVESTIMENTO ESTRANGEIRO: O PADRÃO DE TRATAMENTO JUSTO E EQUITATIVO E O PAPEL DA BOA-FÉ 
Fernando Santos Arenhart

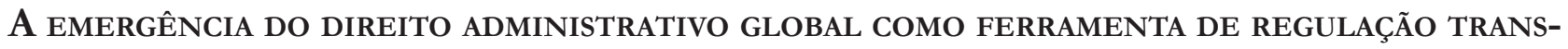
NACIONAL DO INVESTIMENTO ESTRANGEIRO DIRETO .................................................. 171

Andréa Rocha Postiga

Is INVESTMENT ARBITRATION AN APPROPRIATE VENUE FOR ENVIRONMENTAL ISSUES? A LATIN AMERICAN PERSPECTIVE.

Nitish Monebhurrun

A jurisprudência do Superior Tribunal de Justiça e a construção de um Conceito de

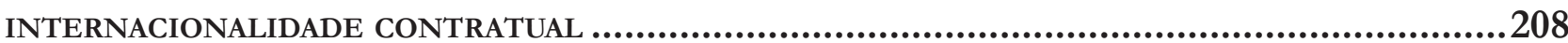

Frederico E. Z. Glitz

IMPACTO E INFLUÊNCIA DOS TRATADOS E CONVENÇÕES INTERNACIONAIS SOBRE A LEI BRASILEIRA DE ARBITRAGEM

Jamile Bergamaschine Mata Diz e Clarissa Correa Neto Ribeiro

A JURISPRUdÊNCIA NORTEAMERICANA E EUROPEIA SOBRE OS ACORDOS HORIZONTAIS E VERTICAIS: SUBSTRATO PARA ANÁLISE DA MATÉRIA NO BRASIL.

Daniel Amin Ferraz 


\title{
Brazilian trade policy in historical perspective: constant features, erratic behavior
}

\author{
Política Externa Brasileira em uma \\ perspectiva histórica: características \\ constantes, comportamento errático*
}

Paulo Roberto de Almeida ${ }^{1}$

Ph.D. in Social Sciences, career diplomat, professor of Political Economy at the PostGraduate Studies in Law of the University Center of Brasília (Uniceub); author of many books and articles on international economic relations and diplomatic history of Brazil and the regional integration process (pralmeida@ me.com; www.pralmeida.org). None of the arguments in this essay is representative of Brazilian official positions or policies of its Foreign ministry.

* Artigo convidado

\section{Abstract}

The essay, which adopts a historical approach, presents and discusses the Brazilian trade policies implemented since the $19^{\text {th }}$ century, as connected with industrial and development policies, not always in a coordinated manner. Brazil was, and probably continues to be, one of the most protectionist countries in the world, at the beginning for fiscal reasons (financing of the State), then, in the $20^{\text {th }}$ century, on behalf of deliberate industrializing and import substitution goals. The essay surveys the many policies followed in different phases of Brazilian economic history, including the regional integration process of Mercosur and the multilateral and hemispheric trade negotiations; it also discusses the recent re-commoditization of its foreign trade and the retrocession to a series of patently defensive policies, justified by a lack of competitiveness of its industries, by the way due to the excessive taxation and the bureaucratic entanglements set up by the very State that seeks to protect those industries from foreign competition. It concludes that a new economic opening or trade liberalization are not likely to occur in the immediate future. Albeit not original in scope or methodology, the essay integrates various sources and specialized literature, offering a synthesis of the state of the art in this field of study.

Keywords: Brazilian protectionism. Trade policies. Industrialization. Mercosur. WTO.

\section{Resumo}

O ensaio, que adota uma metodologia expositiva de caráter histórico, apresenta e discute as políticas comerciais brasileiras adotadas desde o século XIX, tal como correlacionadas com as políticas industriais e de desenvolvimento econômico, embora implementadas de maneira nem sempre coordenada. O Brasil foi, e provavelmente continua sendo, um dos países mais protecionistas do mundo, anteriormente por razões fiscais (equilíbrio das contas públicas) e, a partir do século XX, tendo em vista objetivos deliberadamente industrializantes e de substituição de importações. O ensaio examina as várias políticas seguidas em diferentes fases da história econômica brasileira, inclusive no processo de integração regional do Mercosul e no quadro das negociações comerciais multilaterais e hemisféricas; também discute a recente primarização do seu comércio exterior e o retrocesso re- 
gistrado em termos de políticas abertamente defensivas, que são justificadas pela falta de competitividade das indústrias brasileiras, que é aliás devida à tributação excessiva e as dificuldades burocráticas criadas pelo mesmo Estado que busca proteger essas indústrias da competição externa. Conclui pela escassa viabilidade de uma abertura econômica ou de liberalização comercial no futuro imediato. Embora não original na temática ou na metodologia, o trabalho integra diferentes fontes documentais e a literatura especializada, oferecendo uma síntese dos estudos disponíveis nesse campo de estudo.

Palavras-chave: Protecionismo brasileiro. Políticas comerciais. Industrialização. Mercosul. OMC.

\section{INTRODUCTION: BASIC CHARACTERISTICS}

Trade policy has two constant features in Brazil throughout the ages: one is the country's modest and almost immutable share of the global trade flows for the last half century, and probably since the $19^{\text {th }}$ century; the other is the equally constant belief of its political leadership in the virtues of an industrial policy, which is reflected in an undeniable adherence of its industrial elites to various kinds of protectionist devices.

As regards the first characteristics, it is true that Brazil ratio of global commerce has since long stabilized around a little over $1 \%$ of the world's total interchange of goods and services; it could be argued that Brazil has, at least, kept pace with the progression of trade flows, from the 1950s up to our days, as the share of its foreign trade went along with the faster increase of exchanged goods, over the more moderate growth of the world's GDP. As an excuse for the second feature, that is, for Brazil being a staunch protectionist during most of its economic history, the arguments mobilized by its political and economic elites in favor of those kind of policies take support in ancient mercantilist doctrines that seek to promote national industry and its associated activities, which would be considered by them as unfeasible if undertaken under liberal trade policies or in absence of an active industrial policy.

The moments of economic opening and trade liberalization are indeed very rare in the economic history of Brazil, in a long continuum of various types of defensive policies and state activism that seem embedded in a structural context of political nationalism and economic introversion. As we shall see, Brazil moved away from a strong protectionist industrial policy only for a few times during its successful drive toward industrialization; those moments, by the way, were almost a side effect of an economic policy seeking monetary stabilization or looking for a temporary correction of serious disequilibria in its external economic relations. Crises, internal and external, were the main factors that drove Brazil toward industrialization, at least in the first half of the $20^{\text {th }}$ century. After the Second World War, this objective was pursued much more conscientiously, thus the much more diligent and deliberate choice of industrial and trade policies along defensive and protectionist lines. National development was the consensual ideology of Brazilians during most of the $20^{\text {th }}$ century, and industry was seen as the main tool for the accomplishment of this almost sacred mission.

In recent times, Brazilian civil governments that succeeded the military regime (1964-85) adopted a less strict protectionist policy, but this was only to accommodate the requirements of the integration process in Mercosur; under its scheme, national tariffs of the member countries had to be replaced by a Common External Tariff, with a lower average than the preceding national lists (1994). But that was a temporary relief on a structural defensive behavior that arose again a few years later: trade liberalization policies and tariff reduction measures adopted in the first half of the 1990s, started to be reversed soon afterwards Mercosur became a "customs union" (this in paper, at least).

During the 2000s, Brazilian government refrained from adopting an open protectionist policy only because there was a belief in, and a commitment to, the conclusion of the Doha Round of multilateral trade negotiations; there was also a certain sense of relief derived from the 1999 deep devaluation of the real, which assured, during most of the following decade, confortable gains in the form of trade balance surpluses (not to mention the peaks in commodity prices, which was the "Chinese factor"). As soon as the WTO negotiations foundered, at the end of the 2000's, and the external competitiveness of Brazilian products were slashed by a raise in domestic costs, the defensive posture of the political authorities and the protectionist instinct of the industrialists emerged again, as vibrant as in the old times of import substitution.

This is the basic framework under which one must apprehend the true meaning and the essential nature of 
Brazilian trade policies. The constant features, in historical perspective, are always there, and they are simply mercantilist and truly protectionist. At certain economic junctures it is possible to observe the erratic behavior of the official trade and industrial policies, which can be linked to the trends and flows of the balance of payments, as well to pressures exerted by internal lobbies (from both industrial and workers' unions). In short, those are the constant features of the Brazilian macro and sectorial economic policies. Let's go now for the detailed history of those policies.

\section{Historical development of BRAZILIAN TRADE POLICIES}

The birth of Brazil as a "customs territory", in 1808 , precedes its actual existence as an independent State, which occurred only in 1822. In fact, Brazil did not attain effective customs independence before 1844, but it is interesting to trail the whole story, as it explains the protectionist instincts that Brazil's proprietary and industrial classes would exhibit since then. The departure spot was the 1810 Trade and Navigation Treaty, which Portugal had to accept under the pressure from the English cabinet, after the Royal Navy protected transatlantic retreat to Brasil of the entire court and nobles to scape Portugal's invasion by a Napoleonic army. ${ }^{2}$

Before that, Brazil did not have an independent administration of its foreign trade, for the whole system was working under the "colonial exclusivity", in which the court exerted the monopoly over imports and exports (and prohibited even small industries in the colony, as not to compete with Portuguese supply). All goods had to be carried by Portuguese ships, and pass through Lisbon, except some very few flows allowed under concession or bilateral treaties to be performed by other European merchants (slave traders, would be a more correct designation).

To be true, the first act of a commercial nature undertaken by the Portuguese Prince, arriving in Brazil, in

\footnotetext{
2 Cf. WILCKEN, Patrick, Empire adrift: the portuguese court in Rio de Janeiro, 1808-1821. London: Bloomsbury, 2005; BETHELL, Leslie. The independence of Brazil. In: BETHELL, L. (Ed.). Cambridge bistory of Latin America. Cambridge: Cambridge University Press, 1985. v. 3.
}

January 1808, was to declare Brazilian ports open to all "friendly nations", which at that time comprised only England and Russia, in Europe, and a few other countries in the Americas. The bilateral trade agreement of 1810 benefitted English merchants with a even lower tariff $(15 \%)$ that was applied to the Portuguese goods $(16 \%)$, besides being also a kind of investment treaty, giving extraterritoriality rights to His Majesty subjects, in the same manner of the unequal treaties Great Britain was imposing at that time upon other peripheral countries.

Coming after decades of mercantilist policies applied up to 1808 , and in a juncture when local merchants were preparing to invest their capital in an incipient manufacturing system, the bilateral treaty was seen by contemporaries as an exorbitant concession to England; it came to represent, to later historians, the first obstacle to the creation of industries in Brazil. Even after having proclaimed the independence of the country, the new rulers (half Portuguese, half Brazilians) had to stick to its provisions for another 20 years, as England was the sole source of external financing for the new State. Only to put other countries on the same foothold as the Great Britain, the same concessions in tariffs were gradually extended to those commercial partners under new, albeit similar, bilateral treaties, that were negotiated between 1825 and $1834 .^{3}$

The ruling class of the First Empire badly supported the humiliation, not exactly because the low tariff hindered any intention to industrialize the country, but for the small fiscal revenues it provided to the State treasury and the special privileges the treaty conceded to British subjects (who could not be prosecuted by Brazilian judiciary authorities, being under a special clause of extraterritoriality). Those factors are probably the source of a constant defensive posture maintained by the Brazilian ruling classes throughout the ages in matters of trade negotiations and economic concessions benefiting foreigners, such as investments, acquisition of land, exercise of certain professions or the exploitation of natural resources.

At least, after the denunciation of all commercial treaties with foreign powers and the enactment of a new tariff in 1844, Brazil embarked in one of most defensive trade policies ever seen in the world. Based

\footnotetext{
3 Cf. ALMEIDA, Paulo Roberto de. Formação da diplomacia econômica no Brasil: as relações econômicas internacionais no Império. 2. ed. São Paulo: Senac-SP, 2005.
} 
on the actual receipts of imports reaped by the Brazilian State since the middle of the $19^{\text {th }}$ century up to the 1930's crisis, Clemens and Williamson concluded that Brasil was the most protectionist country in the world (except for a brief period of late Civil War in the United States). ${ }^{4}$ In fact, the aggressive tariffs were not aiming to facilitate any industrial activity in Brazil - which could be a justification for very few cases - but to drain ever more resources to a voracious State (not so different from our days, by the way).

The fiscal pressure exerted over trade policy, effective until the 1930s, had to assume a variety of forms, as the tariffs were not the sole expediency to which the State resorted as a means to replenish its coffers each time. Inflation, devaluation of the currency, changes in the exchange standards and parities, pressures from commercial and industrial lobbies, all contributed to a messy combination of trade and industrial measures that transformed Brazil in a highly bureaucratized State, where erratic or contradictory policies were adopted by successive governments, always under the menace of a default in external payments. The Republic, in 1889, did not correct the confusion, but sustained it. against all odds: as the 1891 Constitution gave large autonomy to the states, they started to tax exports, which multiplied the bias against foreign trade already in force with import tariffs, not to mention the prodigality of external borrowing that federal states and even municipalities began to exert in direction of external sources of financing (most in the City, but also in Paris, and New York). ${ }^{5}$

The Republic also adopted a set of measures destined to promote industrial activity in Brazil, usually with the same bias against foreigners that characterized the old Portuguese mercantilist stance. A law on "national similarity" in fact barred any import of a good that could be produced in Brazil, even at a higher cost and lower quality: formal description was enough to guaran-

\footnotetext{
4 Cf. CLEMENS, Michael; WILLIAMSON, Jeffrey. A tariff-growth paradox?: protection's impact the world around, 1875-1997. NBER Working Paper, Local, n. 8459, 2001. Annex: Import duties over imports, 35 countries, 1865-1950. Available at: <http://www.nber. org/papers/w8459>. Access: May 2, 2013; CLEMENS, Michael; WILLIAMSON, Jeffrey; BLATTMAN, Christopher. Who protected and why?: tariffs the world around 1870-1938. Harvard Institute of Economic Research, Discussion Paper n. 2010, jun. 2003. Available at: $<$ http://post.economics.harvard.edu/hier/2003papers/ 2003list. html>. Access: May 2, 2013.

5 Cf. TOPIK, Steven. Political economy of the Brazilian State, 18891930. Austin: University of Texas Press, 1987.
}

tee a market reserve for the domestic "equivalent". ${ }^{6}$ At the same time Brazil started to be a modest recipient of foreign direct investment, not always regarded with the same empathy as foreign financing: Brazilians usually love foreign capital, but mistrust foreign capitalists.

Economic nationalism received a deep boost during the Vargas era, the 15 years after the Revolution of 1930 that dismantled the old coffee Republic and started to build an industrial, albeit introverted, Brazil. New legislation was enacted in each and every sector to give control of all natural resources to the Union and in many urban activities - in public utilities, for instance - State authorization was required for its exploitation as a temporary concession. ${ }^{7}$ Nationalization of foreign companies was boosted with the Second World War; Brazil became a Bismarckian state, albeit with a very backward agriculture and a still fragmented industry. "Trade policy" at that time consisted only in quantitative prohibitions and the control of imports; the GDP ratio of foreign trade was in a steady decline, and the receipts from exports of a few number of commodities (still concentrated on coffee) were the sole source of foreign exchange. $^{8}$

After being a protectionist by necessity, for fiscal reasons, during most of the $19^{\text {th }}$ century, and also during the First Republic, Brazil became a protectionist by intent; the shortage of foreign exchange did the rest. Anyway, defensive trade policies were maintained by habit, as the importance of the external sector in the overall public planning, for macroeconomic or sectorial purposes, was greatly constrained. At the end of the war, import receipts were as marginal as were direct income taxation, that is, irrelevant for all policy purposes. At the same time, the sustained prices of the commodities and the trade surpluses cumulated during the war, as well as the repression exerted against imports for the whole period, allowed for one of the few instances of trade liberalization: it was, nevertheless, of short duration, as the foreign exchange reserves were quickly depleted and, as soon as 1947, new import controls and a severe restriction on buying foreign exchange (dollars)

\footnotetext{
6 Cf. VILLELA, Annibal Villanova; SUZIGAN, Wilson. Politica do governo e crescimento da economia brasileira, 1889-1945. 2. ed. Rio de Janeiro: IPEA-INPES, 1975.

Cf. VENÂNCIO FILHO, Alberto. A intervenção do estado no domínio econômico: o direito público econômico no Brasil. Rio de Janeiro: Fundação Getúlio Vargas, 1968.

8 Cf. ABREU, Marcelo de Paiva. O Brasil e a economia mundial, 19301945. Rio de Janeiro: Civilização Brasileira, 1999.
} 
were implemented; Brazil started to "manage" contradictory exchange and trade regime for almost 20 years since then. ${ }^{?}$

\section{ReForm AND ADJUStMent to the MULtilate- RAL TRADE SYSTEM}

Brazil, one of the "founding fathers" of the Gatt1947, became an active participant of the U.N. Trade and Employment Conference that, between November 1947 and March 1948, approved the Havana Charter creating the International Trade Organization (ITO), dead at its birth. ${ }^{10}$ Despite the adoption of many mechanisms and policies promoting the industrial sector, Brazil was still a commodity exporter, mainly coffee: for a brief time after the war, its share of the world trade represented a little more than $2 \%$ of the total, but this was only due to the destructions in Europe and Asia. After the high peaks in commodity prices brought by war in Korea, that share has stabilized around 1\%. But the 1950 s and the 60 s were also extraordinary years in terms of industrialization and adoption of trade and industrial policies that were to be the hallmark of Brazilian State planning for the next forty years.

The rationale for the State activism in those areas were of a macroeconomic nature or had a balance of payments justification: living under a scarcity of dollars, inflows of foreign exchange had to depend upon erratic commodity exports; thus, for one side, the need of a restrictive trade policy and, for the other, the very strong and visible hand of the State to promote and sustain the nation's industrial sector. A state company for oil, another for the energy, and a national bank for industrialization were created, together with a flexible exchange rate policy to accommodate the penury of dollars. In 1957, a new trade policy was enacted, with a complete revision of all tariffs, this time with an explicit protectionist bias.

The ad valorem basis of the Empire and First Republic tariffs was replaced in 1934 by a specific tariff, only to be rendered irrelevant by the monetary disorganization

\footnotetext{
9 Cf. BERGSMAN, Joel. Brazil: industrialization and trade policies. London: Oxford University Press, 1970.

10 Cf. ALMEIDA, Paulo Roberto de. Relações internacionais e política externa do Brasil: a diplomacia brasileira no contexto da globalização. Rio de Janeiro: LTC, 2012.
}

of the world, the break-up of exchange patterns, and the running inflation. So the 1957 tariff reintroduced the ad valorem system, but at a much higher levels, thus requiring a complete renegotiation of the Brazilian schedule to the Gatt. ${ }^{11}$ At the same time, the "national similarity" law was reinforced to the point of becoming inexpugnable: all personal vehicles had to be acquired locally, as well as hundreds, many thousands of other durable and non durable goods. ${ }^{12}$ Import bans became the norm.

Current historiography labeled this model as an "import substitution process", inserted in a developmentalist-nationalist context. In fact, most of Latin-American literature about the period take its main concepts from studies and analysis made at the Economic Commission for Latin America and Caribbean of the United Nations, the famous Eclac, under the guidance of the Argentinian Keynesian Raúl Prebisch. The main prescription was industrialization à la List, that is, with the required protection given to the "infant industry" (and remained as such for decades). Regional integration should serve this purpose, otherwise the continent, explained another Prebisch thesis, would be hindered by the constant deterioration of its terms of exchange, due to the inevitable depreciation of the value of commodities, in face of a constant rise in the price of manufactured goods; inflation was a lesser evil, to be tolerated for the sake of growth and employment (income distribution was not yet in debate). Latin America detached itself from the world trade and praised the virtues of self-sufficiency.

In Brazil, public policies as well as the teaching of theoretical economics at the faculties followed the main tenets of Prebisch's heterodoxy, albeit with a certain tension with real world and the empirical economic data. Not surprisingly, state companies, and the public administration in general, performed badly, together with the strengthening of populist and xenophobic bias of many politicians; inflation derailed, due in part to the building of Brasilia, by Kubitschek administration (1956-1960); economic growth and investments declined, and social unrest and military crises made the rest: soon, the middle class was protesting in the streets and querying the Army to restore the order.

\footnotetext{
11 Cf. FARIAS, Rogerio de Souza. Industriais, economistas e diplomatas: o Brasil e as negociações comerciais multilaterais, 1946-1967. 2012. Dissertation (Ph.D.) - Institute of International Relations, University of Brasilia, Brasilia, 2012.

12 Cf. BAER, Werner. The brazilian economy: growth and develop-
} ment. 6. ed. Lynne Rienner, 2007. 
The generals who took over the power in 1964 started a second phase of the Bismarckian project that was launched during the Vargas era: they engaged economists and technocrats to reform every aspect of the Brazilian economic and political life. Fiscal and monetary reforms advanced the modernization of the Brazilian State, and huge infrastructure works were launched. The economic nationalism of the military did not hinder strong flows of foreign direct investments into industry and service sectors. Agriculture was also boosted by research and technological improvements, as well as by post-graduate studies. The intention was to transform Brazil into a "great power" in all areas: aerospace and nuclear industry (not excluding a "dissuasive" device), energy, telecommunications, shipbuilding and the like. Except for oil and capital goods, Brazil achieved $95 \%$ of nationalization by late 1970 s in the domestic current supply.

At that time, Brazil truly became a trade fortress, with plenty of subsidization devices and protective mechanisms in order to transform the structure of the foreign trade. At the end of the military regime, manufactured goods had the greater share of the exports. Brazil's transgressions of multilateral trade rules often generated complaints in Geneva; the usual excuse was balance of payments equilibrium. Another argument in Gatt was that the national industrialization program of a developing country could not be evaluated by the same standards applied to the already industrialized countries.

Brazil was one the most active promoters of the Gatt reform, taking part in the drafting of its Part IV - Trade and Development - and adding the clause of special and differential treatment for developing countries: it was materialized not only by the creation of the GSP (Generalized System of Preferences, based on the principle of non-reciprocity), but also through different rules allowing for greater discrimination against imports and foreign investments. Of course, protectionism continued to be the norm and the accepted behavior of all developing countries, specially those on a industrialization path like Brazil. Even after attaining a degree of concrete industrialization in certain areas even superior to the same sectors in the so called advanced countries, Brazil never accepted its graduation to an upper status in Gatt.

The end of the military regime was abbreviated by the economic crisis induced by the external debt default and its consequences: high inflation, external insolvency, low growth, disorganization of public budgets at all levels of the federation; moreover, regional banks were adding to the domestic debt, by creating "virtual currencies" to service the excess expenditures by state governors. At the Union level, Brazil had not only one, but three budgets, with a set of different provisions in each: first, the normal fiscal accounting of receipts and expenditures (the only approved by the Parliament); there was also a monetary budget, operated at the discretion of the financial authorities (that is, whenever the central government needed more resources, it printed money); the third, and sometimes highly relevant, worked just for the state companies (which were responsible, at that time, for $35 \%$ of the GDP, and literally monopolized entire sectors of the economy (the "commanding heights", or strategic areas, which were many, like steel, communications, transports, oil, shipbuilding, aeronautics, etc.); this last one could be occasionally used for balance of payments purposes (that is, going to external lending, attracting foreign investments, and so on).

At a certain point, specially after the external debt crisis of 1982 - which lasted throughout the 1990s industrial and trade policies were at the service of the balance of payments equilibrium; no surprise, them, that distortions grew at every sector of the economy, and protectionism became the norm, not the exception. Brazil was frequently asked to explain foreign trade restriction to its partners of the Gatt: the standard answer was that exchange restrictions dictated the "temporary" administration of the external trade, the quantitative restrictions, and the high tariffs (sometimes more than $100 \%)$.

The return to a civilian administration, in 1985, did nothing to stabilize Brazil; on the contrary: "democratic" pressures materialized in larger social expenditures and a new Constitution (in 1988) added to the disorganization of public accounts, commanding many new entitlements not properly funded by real resources, only by paper money. Few countries in the world experienced the curious phenomenon of "controlled hyperinflation", that is, the continuous depreciation of the currency - Brazil had six in less than 8 years - neutralized only by a total indexation of the economy.

At the height of the crisis, monetary authorities introduced more capital controls, adopted the centralization of foreign exchange - the black market worked, some- 
times, at $60 \%$ of the official rate - and declared a moratorium on the service of external debt. Inflation went over the barrier of two digits a month, and three digits a year; in less than six years Brazil had four new currencies: cruzado (replacing the cruzeiro in 1986), cruzado novo two years after, cruzeiro again in 1991, and cruzeiro real, soon afterwards, only to be superseded by the real in 1994 (with and indexed currency in between). ${ }^{13}$

\section{Regional integration process and the Mercosur Path}

By the end of the 1980s, the overstretched industrial and trade policies were not responding to any rational objectives. The 1988 Constitution created new, costly rights for everyone: health, education, social security, federal transfers were granted, disregarding completely the question of how or who would fund the new entitlements. The modernizing administration of Collor de Mello (1990-92) started a complete overhaul of the old economic mechanisms and sectorial devices inherited from the military regime that were further distorted by the subsequent civilian government. Notwithstanding the freezing of financial assets (that created many other distortions), the radical reform launched at the onset of "Collor plan" touched the various industrial mechanis$\mathrm{ms}$ - discriminatory and xenophobic, and heavily subsidized, such as the market reserve for informatics - that were at the core of the "industrial Stalinism" created by the military, and scratched completely the corresponding trade policies: import bans were lifted, hundreds of norms revoked, and a tariff reform (scheduled in three years) started to bring the average $44 \%$ of import duties to a more "normal" $14 \%$.

Bilateral economic integration with Argentina was being pursued since the democratization: first under sectorial protocols, then by means of a common market treaty (1988), due to be completed in 10 years, and finally, in 1990, with dispositions that changed the methodology, establishing a full free trade zone and a cus-

\footnotetext{
13 For a detailed account of hyperinflation in Brazil and the various stabilization plans see: FRANCO, Gustavo. O plano real e outros ensaios. Rio de Janeiro: Francisco Alves, 1995; PRADO, Maria Clara R. M. do. A real história do Real: uma radiografia da moeda que mudou o Brasil. Rio de Janeiro: Record, 2005; LEITÃO, Miriam. Saga: a luta do povo brasileiro em defesa da sua moeda. Rio de Janeiro: Record, 2011.
}

toms union in half of that time frame, promised for 1995. With the incorporation of Paraguay and Uruguay into the bilateral scheme in 1991, the Mercosur treaty was signed, which contributed to the consolidation of many changes being applied domestically.

At the same time, the Uruguay Round come, finally, to completion, helping also to lock out some reforms and opening policy spaces for the enactment of new legislation in many fields that were also at the heart of the old industrial and trade policies (intellectual property, for instance, besides the completion of the Common External Tariff of Mercosur, that replaced, in 1995, the Brazilian customs duties). ${ }^{14}$ Regional integration could help, in due course, the cause of a more rational macroeconomic and sectorial policies, including the erratic trade policy, if only the founding treaty commitments were respected, which was never the case.

The new WTO agreements - Gatt-1994, as well as the various protocols that came together - and the building up of Mercosur trade structure added to the ongoing process of economic opening, trade liberalization and, most important, the retreat of the State from the commanding heights of the economy (a task never completed, to be sure). Fernando Henrique Cardoso, first as Finance minister (from 1993), after as president, in two mandates (1995 to 2002), lead the most relevant process of economic reform since the Vargas era: FHC advanced the privatization of State companies and the dismantling of public monopolies that were initiated by Collor; he also undertook the difficult task of amending the economic chapter of the 1988 Constitution, a ugly assemblage of naked irrationalities and pure xenophobia that were discouraging the domestic entrepreneurs and worrying foreign investors. He barely conceived any new kind of industrial policy - besides eliminating costly subsidies to inefficient producers in new and old industries - and made no advancements to the trade policies already in place during the transitional phase of the Mercosur (1991-1994).

In fact, Mercosur started to derail from its original inception almost immediately after becoming an official "customs union", in January 1995. Argentina first, Brazil soon afterwards, both confronted to declining trade surpluses (in the case of Argentina, deepening deficits) and growing external competition from third partners,

\footnotetext{
${ }^{14}$ Cf. ALMEIDA, Paulo Roberto de. Mercosul: fundamentos e perspectivas. São Paulo: LTr, 1998.
} 
resorted to tariff increases, albeit in a disguised manner: Argentina by the implementation of a "statistical tax", Brazil by limiting the offer of trade credit by external financing, and both by arbitrarily including many products in national exception lists, thus departing from the Common External Tariff. Despite being a "customs union", member countries were unable to set up a Customs Code, to be applied homogenously by their national customs administrations (or, preferably, by a single customs authority): Mercosur never ceased to be a permanent "customs union in construction", each time pierced by new, non regulated national exemptions from the common rules. Worse encore: what was not supposed to arrive in a free trade area or in a customs union, started to happen, by means of restrictions to intra-trade; barriers against the free flows of goods under the pretext of dumping or unfair competition (originating mainly in Argentina, against Brazilian products), that were unable to be solved by Mercosur's dispute settlements mechanism, had to be transposed to the arbitration system of the Gatt-WTO. ${ }^{15}$

Notwithstanding, Mercosur member countries started to negotiate conjointly the U.S. proposal for a new trade pact to cover the whole hemisphere: the Free Trade Area of the Americas, launched at a summit in Miami, in December 1994, and due to be completed in ten years. Argentina, under Menem (1990-99), was much more favorable to the American project than Brazil, a posture that was to be radically reversed after the dramatic economic crisis of 2001, and the new (2003) nationalist government of Nestor Kirchner. Brazil too, never sympathetic to the idea of opening its economy to the giant of North America, dragged its feet in the negotiations, albeit seriously considering the possibility of a certain degree of trade and services liberalization, provided that U.S. offered real market access to its exports of farm products and competitive industries (in a direct challenge to sectorial American protected and subsided branches).

The cooperative posture of FHC administration during the first phase of FTAA negotiations was also radically reversed by the new Workers' Party govern-

\footnotetext{
15 For a history and an evaluation of Mercosur's itinerary, see ALMEIDA, Paulo R. História do Mercosul: origens e desenvolvimento. Espaço da Sophia, v. 5, n. 43, p. 63-79, jul./sep. 2011; ALMEIDA, Paulo R. História do Mercosul (2): crise e perspectivas no século XXI, Espaço da Sophia, v. 5, n. 44, p. 143-170, oct./dec. 2011. Available at: <http://www.espacodasophia.com.br/revista/>.
}

ment leaded by Lula da Silva, who labeled the American proposal not an integration scheme but an "annexation project"; in fact, no technical studies were made to assess the real impact of a hypothetical FTAA in Brazil's or Mercosur economies: Lula's government simply abhorred the idea of an economic integration between South and North America. ${ }^{16}$

To summarize a very complex process, the fact is that both Kirchner's Argentina and Lula's Brazil, together with Chávez's Venezuela, cooperated actively to implode the American project, not on economic grounds, but for pure political (and ideological) opposition. The clash intervened at the Americas summit in Mar del Plata, in November 2005, when those three countries started to taking a very different path than the one followed by the reforming Latin American administrations during the 1990s; the previous years were outright condemned as neoliberal, as the "progressive" leaders started to proclaim the new virtues of the old developmentalism. In fact, a new kind of economic policy began to bring them towards the past, carrying with it some old distortions of the former nationalist and introverted model of development.

\section{Real Challenges AND lost OPPORTUNities: Brazilian ILLUSIONS AND DECEPTIONS}

With some differences in speeches, but with the same acuity in the political criticism, both administrations, Nestor Kirchner in Argentina, and Lula in Brazil, merged efforts, from 2003 onwards, in the attacks to the alleged "neoliberalism" of their predecessors. The arguments used for the dismantling of previous economic policies were totally ideological in nature, but the practical consequences were relevant, and in some ca-

${ }^{16}$ For a discussion on the main choices of the Brazilian diplomacy during Lula's two mandates, see ALMEIDA, Paulo R. Never before seen in Brazil: Lula's grand diplomacy. Revista Brasileira de Política Internacional, v. 53, n. 2, p. 160-177, 2010. Available at: <http:// www.scielo.br/pdf/rbpi/v53n2/09.pdf>.; ALMEIDA, Paulo R.: La diplomatie de Lula (2003-2010): une analyse des résultats. In: ROLLAND, Denis; LESSA, Antonio Carlos (Coord.). Relations internationales du Brésil: les chemins de la puissance. Paris: L'Harmattan, 2010. v. 1, p. 249-259. Available at: <http://diplomatizzando.blogspot. com/2010/ 10/relations-internationales-du-bresil.html>. ALMEIDA, Paulo R. Lula's foreign policy: regional and global strategies. In: BAER, Werner; LOVE, Joseph (Ed.). Brazil under Lula. New York: Palgrave-Macmillan, 2009. p. 167-183. Available at: <http://www. pralmeida.org/05DocsPRA/1811BrForPolicyPalgrave2009.pdf > . 
ses very regressive in their naif return to the old times of economic nationalism and State control of strategic activities. True, the reversion was much more dramatic in the case of Argentina, than in the Brazilian itinerary followed by Lula and his economic advisers. The reasons for this difference were not ideological, but the very contrasted situation of the two countries, Brazil having stabilized soon after the turbulent times of the financial crises of the 1990s, and Argentina still in the turmoil of the catastrophic ending of the fixed currency regime established by the 1991 Cavallo plan.

After the economic reforms - and some political chaos - introduced by the Collor presidency, Brazil reached, finally, a more normal economic behavior, under Cardoso as Finance minister (1993-94) and during his two presidential mandates (until 2002). The financial crisis iniciated by the frustrated currency devaluation in Mexico (December 1994) set the departure mark for a world financial storm that occurred some months later: first with the Asian exchange crises started by Thailand's insolvency (June 1997), then the stock exchange plunge in Hong Kong (October), followed by the political-economic crises in almost every other country of Asia Pacific. Brazil managed to contain the capital flight, only by resorting to an extraordinary rise in interest rates. The grievous effects of the Russian moratorium of July 1998, though, could only be defused by a stand-by arrangement with the IMF and the financial help of other creditor countries. Soon afterwards, political disagreements between FHC and his former boss, vice-president turned president Itamar Franco (1992-94), again governor of Minas Gerais in 1995, provoked the dramatic devaluation of the Real and an economic reversal of the exchange policy, which started to work under a flotation system.

But, new surprises expected at the corner: after the external balance was restored in early 2000 - allowing Brazil to repay some of the financing received in 199899 - it was time for Argentina enter into a free economic fall, followed by the social unrest and an overall presidential turnover at the end of the year. Brazil had to enter into a new agreement with the IMF, in 2001 for more than US\$ 15 billion - only to renew the move the following year, with the doubling of the financing, all this at the height of the presidential campaign that, finally, brought Lula to the presidency.

The main political effect of all those financial crises and changes in economic policy in Brazil was to convince Lula that he could not possibly apply the economic receipts prescribed by the "economists" of his own party. Having already been defeated in the previous three attempts to become president, he assumed the practical conclusion that he had to stick pragmatically to the same "neoliberal" policies implemented by his predecessor. Indeed, instead of "changing it all", as his campaign had announced optimistically, he changed nothing, and even preserved technocrats from the social-democrat government of the previous years. Better: the new economic authorities reinforced the economic mechanisms negotiated with the IMF (for instance, the primary surplus in the budget, to pay for the public debt interests), and adopted an overall "neoliberal" approach to other macroeconomic and sectorial policies.

In short, "thanks" for the many disasters in Latin America, and his own unsuccessful electoral failures three times previously, Lula choose to be much more like Felipe Gonzalez - who presided over than a decade of economic growth and unemployment reduction in Spain - than Salvador Allende, the men who launched Chile into a political and economic disaster, due to his socialist receipts: nationalization, State command, inflation prone macroeconomic and sectorial policies, large benefits to workers and small peasants, economic pressure over capitalists or outright expropriation of large land tenures, and open hostility towards foreign investments.

Having learned a little from that, Lula disregarded his own party's "economists" guidance, and choose the rational way of applying practical economics. This was not an impediment to renew with some bad habits of the military regime (some of them were no so secretly admired by the leftist economists): growing State expenditures, the creation of public companies, the belief in the visible hand of the State guiding the markets, as well as some permanent beliefs of the Left: indexation of wages, generous dispensations for the workers and entitlements for the poor people, redistribution from above (that is, not by employment and the markets, but through the alleged social correctness of the technocrats), and so on.

To summing up, the results of Lula's moderate expansionary monetary and economic policies were: the rise of public expenditures (above and beyond economic growth and inflation levels), more crowding-out in face of an already low pattern of domestic savings, 
an expanded bureaucracy, more public servants, and more regulations (much more than needed for a emerging market economy). Growth was pushed by external demand, mainly by China hunger for commodities (of which Brazil has plenty of), and by internal demand, also stimulated by the expansion of consumption credit (with a financial market characterized by a share of public banking equivalent to $40 \%$ of the total credit). Social policies were truly redistributive, albeit much more based on the over taxation of wage workers and entrepreneurs, than in expanded investments and reform; in fact, there was no elimination of poverty, only consumption subsidies to the poor channeled by means of Bolsa Familia, which is an important electoral device.

In terms of trade policy, Lula's government undertook the task of diversifying markets, not exactly as the outcome of a careful study of new opportunities in emerging countries, but as an decision taken on the basis of a political choice: Lula himself proclaimed the objective of "reducing the commercial dependence [sic] from the United States", and of creating a "new world trade geography" (whatever it meant). In 2009, China became, as a consequence, the first trade partner of Brazil, but a new dependence was created, worse than that supposedly prevailing in the bilateral trade with the U.S.: against the much more diversified trade relationship with the "American empire", the flows between China and Brazil were the perfect reproduction of former colonial ties from a century earlier, that is, commodities from Brazil (and just 5 or 6 , that totaled $95 \%$ of Brazilian exports), and manufactures from China, plenty of them, electronics, textiles and apparel, shoes, parts and pieces, all kinds of gadgets.

In the end, Brazil reduced its historical external vulnerability - by accumulating huge foreign reserves - and expanded domestic levels of employment. But the absence of real economic reforms (specially in the taxation system), together with the erosion of the quality of economic policies (and even of public institutions, like the Parliament, no to mention public education), joined in a perverse combination of factors that led to the worsening of external (even domestic) competitiveness of Brazilian companies and to the precocious specter of "deindustrialization". Despite the favorable external climate for growth and development, and the adjustments made in the domestic policies by Cardoso's administration, Lula's years were a lost opportunity for reform and for the strengthening of Brazilian economy to tackle the challenges of globalization.

\section{What WENT WRONG? BRAZIL RETROCEDES INTO PROTECTIONISM}

It is true that, despite the formal adherence to a set of typical Keynesian-like, Latin American developmentalist economic policies, Lula's two governments did not operated a full return to the worst aspects of the economic regime in place for many decades before Cardoso lead a conceptual revolution in the very heart of the Brazilian state. After promising to change everything and creating the very crisis for which he accused his predecessor, telling about his "damned legacy" - Lula behave at least cautiously: privatizations were not reversed (albeit they were curtailed short), the intellectual property law granting patenting for previously excluded sectors was not abolished, neither were the many constitutional amendments by means of which most of the discrimination against foreign companies were eliminated; in short, neoliberalism was pursued, under new clothes.

But plenty of old and new devices were introduced to accomplish or strengthen some of the traditional obsessions of the "economic Left": the reintroduction of some type of market reserve for national companies; preeminence given, again, to the State companies, and the creation of new ones; a set of selective preferences in government procurement, based on an informal "national similarity law", including allowing for a $25 \%$ overprice for buying national; bureaucratic requirements of local content in high linkages productive branches; preservation of legal barriers to foreign investments in many sectors; a tentative limitation of land acquisition by foreigners; and an alternative foreign trade policy based on ideological sympathies towards narrowly defined "strategic partners", much more than in pragmatic considerations.

It is true, too, that Lula's administration did not surrendered to the worst instincts of that economic Left, such as the primitive protectionist devices of the import substitution era, the extensive currency and capital controls in practice for many decades before the 1990s, or an extensive manipulation of exchange rates; it also generally respected the autonomy - which does not 
meant independence - of the monetary committee of the Central Bank in the management of interest rates and other exchange mechanisms. But it did nothing, conversely, to make advances in economic opening, to further trade liberalization or start real negotiations to achieve significant commercial agreements, besides a few totally irrelevant Mercosur preferential arrangements with a very limited number of partners. It must be clearly stated that it refrained from explicit protectionism normally preferred by the Left only because one of its priorities in foreign policy was the conclusion of the Doha Round of multilateral trade negotiations, in the framework of which it sought a Mercosur trade alliance with European Union; but there was no great enthusiasm to make greater concessions, including in new areas, as Lula government kept repeating the old mantra of "policy spaces for development policies", which always represented an almost empty slogan.

Incidentally, the attraction of foreign direct investment, which was one of his constant appeals, was conceived much more as a means to create new domestic employment opportunities and to stimulate and increase the internal market, than as a full scope strategy to insert more vigorously the Brazilian economy in the globalization process. Mercosur, originally, was explicitly conceived with this objective in mind, but since Lula has been transformed in a political forum, voiding its true economic content.

Even the political offensive in South America, another of its priorities, was devised mainly to open new opportunities to big Brazilian companies in neighboring markets (with plenty of official financing coming at reduced rates from BNDES, the national development bank), instead of creating a truly integrated economic space in the region. By any means, the retrocession to economic nationalism, the state dirigisme and associated populist practices, in implementation by many of Lula's "progressive" fellow presidents, is anything but conducive to real economic integration. Special preferences given to some "strategic partners" in the regional scenario (with the "Bolivarian states", for instance) and in other continents (Russia and China, mainly, but also with some least recommendable states, such as Iran) were devised and implemented with grand political objectives in view, beyond and aside more concrete national economic interests.

Albeit not resorting to the worst examples of "socialist" travails on the way in, and in the manner of,
Bolivarian countries, one country, Argentina, decided anyway to adopt a complete set of economic features which implied, in practice, many steps backwards towards the high times of import substitution industrialization and of protectionist policies of the 1960s and 70s. They were unleashed soon afterwards Nestor Kirchner started his presidency, in the middle of 2003, having already benefitted of the full political support from Lula in his campaign against the same Menem of "neoliberal" times. The first move by both presidents was an attempt to replace the well-know Washington Consensus - a practical guide for reform and adjustment in Latin American countries in ten big principles - by a so-called "Buenos Aires Consensus": the document, negotiated almost secretively by radical Keynesians of both countries, before being approved by presidents in their first working summit, dispensed much more social receipts for a fair treatment of the poor people than prescribed macroeconomic or sectorial policies in substitution to the market recommendations of the original John Williamson synthesis. If they expected the new Consensus to be willingly adopted by other countries in South America, frustration was the sole response: only indifference gratified a bizarre search for an alternative to the hard realities of the market economy.

The conceptual framework under which the document was conceived offered, nevertheless, a basis for an overall dirigiste approach to economic policy, which was applied in Kirchner's Argentina in a more consistent way than in Lula's Brazil. It's a fact that, from Kirchner (Nestor) to Kirchner (Cristina), Argentina went back many decades, in terms of macroeconomic and sectorial policies: starting with manipulating inflation indicators from 2007 up to our days - which finally prompted an official alert from the IMF - their governments gradually increased the array of interventionist measures in every sector of national economy: from abusive retenciones - that is, a levy on exports of grains, meat and other primary commodities to the renationalization of foreign owned companies and economic pressure over non complying media vehicles, the two presidents exerted all types of government intrusion on private activities of companies and individuals. In a certain sense, Argentina was taken back to the 1960s', as regards trade and investment policies, and perhaps to the 1930s', as far as monetary and currency regimes are concerned; Brazil didn't go, or is not (yet?) there.

Brazil started to adopt a vaguely similar economic model on the trade front only after Dilma Rousseff 
became president, starting in 2011. But, in the meantime, Lula was highly tolerant towards the truly distorting protectionist devices that Argentina erected against imports in general, and to counter Brazilian exports in particular. In fact, Argentina was contradicting not only the letter and the spirit of Mercosur trade agreements - which commanded, in principle, a free trade zone among the four member countries, that should be in place since 1995 - but also opposing the very dispositions of the safeguards protocol of the Gatt system; in a word, Argentina was acting not only arbitrarily within Mercosur, but as well in an illegal and discriminatory manner in the context of the multilateral trade system administered by the WTO.

Indifferent to the fact that those abusive restrictions were hurting Brazilian industrialists - specially those of domestic utilities of the white line, and light industry in general - Lula adopted a passive posture when confronted with Argentinean protectionism in practice: the only argument was that Brazil showed a consistent surplus balance in the bilateral balance, and could, thus, display some kind of "generosity diplomacy", giving Argentina a breathing space to reindustrialize the country after the 2001-2002 crisis. Argentina, struggling to resume normal economic life after the moratorium and the radical change in its monetary and exchange regimes, started to impose restrictions on external trade, that is, imports, even from its Mercosur partners.

First, Kirchner government tried to impose to Brazil a strictly balanced bilateral trade, allowing for compensations in case of exchange devaluation, quantitative limitations and other correction mechanisms; then, Brazil and Argentina agreed to establish some corrective mechanism of the bilateral commercial and financial imbalances. Sometime between 2004 and 2005, and after some squabble over the modalities of those compensating devices, the two countries implemented - not in the framework of Mercosur, which would be the more appropriate, but only bilaterally - a system to be designed as MAC, Mechanism of Competitive Adjustment, with the objective of legalizing the unilateral restrictions imposed by Argentina. ${ }^{17}$

\footnotetext{
17 It is relevant to clarify that, at the initial stages of the evaluation of Argentina's proposal by the Brazilian government, the technical staff in Itamaraty - that is, its diplomatic corps engaged in integration affairs - was opposed to the mechanism of compensation suggested by Argentina, considering that its introduction was inconsistent with Mercosur rules, but the decision had already been taken,
}

In the end, even allowing for the resumption of bilateral trade and the normal increase in commercial and investment flows between the two countries after Argentina renewing with economic growth, a negative result of those restrictions was the relative decrease of the share of Mercosur in the total external exchanges of Brazil: from a high rate of almost $16 \%$ of its global foreign trade before the 1999 exchange crisis, intra-regional flows remained below 10\% in the geographical Brazilian trade distribution, even with a progressive rise in volume and value (but always below the overall trade growth). Worse, with the growing inflation and exchange distortions cumulating in Argentina, its government started to multiply trade restrictions, which resulted in actual absolute decrease of Brazil's exports to Argentina, the third major in importance (after China and the U.S., not counting the European Union as a bloc).

But those were concrete manifestations of the abusive trade restrictions taken unilaterally by Argentina, which could be considered, from a neutral standpoint, as unintended consequences of its adjustments to a post-crisis scenario. However, Brazil itself choose to implement its own trade restrictions, also renewing with old practices of the 1960s' and 70s'. They were conceived, at first, to help the local automotive industry sustain the competition from cheaper vehicles imported from Asia, which were hurting the old local plants, mainly composed of American and European marks; it is true, also, that most of those industries are located near São Paulo, whose industrial suburbs are the core of metallurgical trade unions and of the workers central unions that were to be a basis for the creation of Lula's Workers' Party in 1980. The government imposed, starting in 2011, an extra-tax on imported vehicles not complying with a obviously abusive requirement of $60 \%$ local content, a decision which is clearly inconsistent with the WTO agreement on Trims (Trade related aspects of investment measures); again, it defined, afterwards, a policy to stimulate investments in the same area, which included many restrictive requirements regulated by Trims and other WTO agreements.

At the general level of trade policy, many new barriers were erected against imports of industrial competing manufactures according to a very used scenario: after complaints by entrepreneurs from exposed branches, the government invariably invoked some reason

politically, in the Presidency, to accept this bizarre scheme. 
of high social impact - that is, unemployment - to adopt defensive measures, generally expressed in terms of tariff rises (but also antidumping). In the absence of fixes at Mercosur level - for instance, higher duties in the Common External Tariff - the products are included in a national exception list (which should be, in principle, temporary). In practice, taking into account the extension and variety of protectionist devices, it could be said that Brazilian government abandoned any perspective of finishing the Doha Round of multilateral trade negotiations. ${ }^{18}$

\section{What LIES AHEAD: A FORTRESS BRAZIL OR AN OPENING TO GLOBALIZATION?}

In September 2013, a Brazilian diplomat, Roberto Azevedo, started as the new Director General of the WTO, after a tiresome campaign that led him to pay visits in every continent and to a vast number of member countries. This is simple a fact, being also facts that he received his many votes from the large majority of developing member countries and that he received less support, or scant votes, from the biggest trade partners, whose relative number is probably the inverse of their share of the world trade. But it is also a fact that developing countries, and some of the biggest trade players among them - such as China, the greatest importer and exporter in the world, together with Brazil, Russia, India, Indonesia, and many others - have today a larger participation in the world flows of goods than it was the case when WTO emerged, at the end of Uruguay Round.

The big question arising from those simple facts is to discern what his success in being chosen to lead an important organization as the WTO means for Brazil, as well as for the future of the multilateral trade? Having been the Brazilian representative in Geneva for the five previous years, and, before that, as the official responsible for trade negotiations in the Brazilian ministry of Foreign Affairs, Ambassador Azevedo was one of the most knowledgeable person about the Doha Round and the foreign trade policy of Brazil, having as such established his credentials as a fine negotiator and as a trustful person from the stand point of almost every

18 Cf. RICUPERO, Rubens. A maior mudança da política externa. Politica externa, v. 21, n. 3, p. 95-100, jan./mar. 2013. one of the WTO members, including the advanced countries, that denied him their final votes.

No one, however, would deny his personal capacity and technical competence as a front line operator for Brazil during the agonizing phase of the Doha Round, from 2009 to our days. This is a fact, being also a fact that he was not among the policy makers behind the instructions he was receiving from Brasilia; those directives were taken at a higher decision level than was the case even when he was in charge of the multilateral economic affairs in the Itamaraty. There is another fact that one have to recognize that Itamaraty was no more the fulcrum of the decision making process in terms of trade policy, having being sideline from the center by people working at the two most important economic ministries: Finance and Foreign Trade.

It is clear, from what already has been said in the preceding sections, that Brazil became a, or returned to, a basic commodity exporter, which it was until the 1960s: much like its traditional concentration in a few primary commodities for centuries, until the industrialization drive of the middle $20^{\text {th }}$ century, its trade balance became heavily dependent of five or six main agricultural products and iron ore. It is also clear that, policies and measures which could be supposed to have being abandoned since the 1990s, are back again, with a renewed impulse. Those are not the multilateral trading policies designed at Itamaraty, but a new set of guidelines arising from an little bunch of developmentalist Keynesians of the old style at the two other ministries.

Not that Itamaraty could be considered as a beacon of classical liberal thinking among the mercantilists; to the contrary: diplomats also share a distinct appreciation for developmentalist policies of the classical Cepalian kind, that is, Prebischian Keynesianism, albeit moderate and of a more sophisticated species. But they had to admit that ideological preferences of the new rulers were being tilted not towards Adam Smith, but in the direction of Friedrich List and Mihail Manoilescu. ${ }^{19}$ In short, with the crisis of 2008-2009, and the

\footnotetext{
19 Both well-known ideologues of the managed trade and of protectionism were always praised and much appreciated among and by economists, industrialists and decision makers in Brazil, since long; see ALMEIDA, Paulo R. Brazilian economic historiography: an essay on bibliographical synthesis. In: ANNUAL CONFERENCE OF THE ECONOMIC \& BUSINESS HISTORICAL SOCIETY, 38., May 23-25, 2003, Baltimore, Maryland. Historiografia econômica brasileira. Revista de Economia e Relações Internacionais, v. 11, n. 21,
} 
dim prospects of a successful conclusion of the Doha Round, together with the vanishing trade surpluses in Brazil's balance of payments, protectionism became the norm, not the exception. Irony of the ironies: the new (or renewed) condition of commodity specialization was construed at the same time that Lula's government declared very clearly its preference for a "strategic partnership" with China, which was supposed to establish a reciprocally beneficial relationship with Brazil (having become its first trading partner in 2009), including the full support of the Asian giant for the eternal Brazilian quest for a permanent chair in the UN Security Council. For the sake of its political coherence, Lula and Dilma administration never blamed China for any kind of disloyal trade, State subsidies or currency war, preferring to accuse both U.S. and EU of protectionism and "ffinancial tsunami".

Having those facts into account, what could be future behavior of the new Director General of WTO? ${ }^{20}$ To begin with, he will have to put in the agenda and tackle already made complaints by the most important trading partners of Brazil - U.S., EU and Japan, with the exception, for the moment, of China - against measures of trade and industrial policy which are unquestionably biased towards local companies, or national providers, discriminating against foreign suppliers, either by tariff devices or fiscal facilities conceded in connection with local content. Many of the defensive measures adopted in the last two years seems to violate the investment agreement (Trims) accepted by Brazil in the outcome of Uruguay Round and the creation of the WTO. Secondly, he has to balance his independence and neutrality as the General Director against the fact that he is also a relatively junior Ambassador who will probably return to his diplomatic career, after one or two mandates in the WTO management.

It is also almost an established fact that Brazil will continue to assist, in the foreseeable future, a progressive deterioration of its external position, which is surely to be reflected in growing transaction accounts deficits. Brazilian economy endures a standstill and persists in a quasi-stationary state, characterized by low growth rates and high inflation (in the average, the double of

p. 5-21, jul. 2012.

${ }^{20}$ In an interview he gave shortly after being elected, Ambassador Azevedo stated very clearly his free trade credentials; Cf. AZEVEDO, Roberto. O novo guardião do livre mercado. Veja, n. 2322, May 22, 2013. other emerging countries); furthermore, its exporters lose competitiveness, abroad as well as in the internal market, and most of its entrepreneurs suffer from one of the most difficult business environment in the world, made of high taxation, bureaucratic entanglements, excessive State regulation, poor infrastructure, and many other negative features of its cartelized and over protected markets. If it was not for its high competitive agribusiness, and the relatively huge foreign currency reserves, the looming current transaction deficit might be already taken the format of a crisis.

In the absence of a courageous and serious attempt at structural reforms - which in any case would require some time to be effective - to improve productivity levels and give a new impetus to its weakening industrial basis, the most probable outcome of the current situation is a strengthening of the protectionist instincts of Dilma Rousseff's government and the continuation of its piece-meal approach to sectorial reforms, made of limited, partial and temporary tax reductions, together with credit largesse by the BNDES and extended financing by the official banks (which today are responsible for almost half of all financial borrowing in Brazil). The worsening fiscal situation will probably not facilitate the adoption of any huge horizontal program of innovation enhancement for the industry, and the initiatives at vertical stimulus to a selected chosen few of prospective "champions" at world level have already proved unsuccessful. The industrialists have also already perceived that limited tax reduction, modest currency devaluation and some official credits will not solve Brazilian structural problems; they will continue, then, to suggest "temporary" protection, more introversion towards internal market, and the negotiation of significant trade pacts to guarantee market access at targeted economies. But even that is showing uncertain or moderate alleviation from the current economic ills.

It seems improbable, then, that Brazil should take a decisive road towards globalization and a new economic opening, least of a radical departure from the economic ideology of its current leaders (or a fall in the tribulations of a new economic crisis). It is also unlikely the erection of a national commercial fortress, as Brazil has to abide to some existing rules of Mercosur and it can strengthen the economic ties in the South American context. But it is also true that Argentina and Venezuela are on the verge of serious domestic and external crises, and that the Pacific coast neighbors - namely Chile, 
Peru, Colombia, not to mention Mexico, further North - are aggressively seeking expanded linkages, of commercial and investment types, with the whole Pacific basin. Even in its South American "chasse gardée", China is making inroads of a multiple nature, which reduces a little more the maneuvering space of the Brazilian businessmen in the region. Incidentally, even initiatives that Brazil promoted in the recent past, in the wake of political enthusiasm with its "South-South diplomacy", such as trade pacts among developing countries, have not yet received the signing of the presidency and the subsequent approval of the Congress; well, legislators will probably ax many tariff concessions in a growing range of endangered Brazilian industries.

Decidedly, times are not favorably for a bright Brazilian future in the new global economy, as it spent most of the last ten years surfing in the Chinese commodity bonanza, without taking the effort to reform and modernize its economic industrial basis or to run after trade pacts that could guarantee some market access and specialized niches in relevant countries. A probable evolution could be designed in the form of a continued erosion of its competitive position around the world, accompanied by an introspective posture that should reinforce the same traits that are being consolidated as defensive policies nowadays. Trade and industrial policies have always been devised and implemented as complementary tools in favor of the national sacred mission of industrialization. As the current national drama assumes the ugly feature of de-industrialization, Brazilian leaders will have to scrap old economic ideologies and start to thinking about structural reforms again. History is not kind with hesitant and dubitative leaders; decadence is not a better alternative.

[Hartford, May 14, 2013; revised: May 20]

\section{REFERÊNCIAS}

ABREU, Marcelo de Paiva. O Brasile a economia mundial, 1930-1945. Rio de Janeiro: Civilização Brasileira, 1999.

ALMEIDA, Paulo R. História do Mercosul (2): crise e perspectivas no século XXI, Espaço da Sophia, v. 5, n. 44, p. 143-170, oct./dec. 2011. Available at: <http://www. espacodasophia.com.br/revista/>.

ALMEIDA, Paulo R. Brazilian economic historio- graphy: an essay on bibliographical synthesis. In: ANNUAL CONFERENCE OF THE ECONOMIC \& BUSINESS HISTORICAL SOCIETY, 38., May 23-25, 2003, Baltimore, Maryland. Historiografia econômica brasileira. Revista de Economia e Relações Internacionais, v. 11, n. 21, p. 5-21, jul. 2012.

ALMEIDA, Paulo R. História do Mercosul: origens e desenvolvimento. Espaço da Sophia, v. 5, n. 43, p. 63-79, jul./sep. 2011.

ALMEIDA, Paulo R. Never before seen in Brazil: Lula's grand diplomacy. Revista Brasileira de Política Internacional, v. 53, n. 2, p. 160-177, 2010. Available at: <http://www. scielo.br/pdf/rbpi/v53n2/09.pdf>.

ALMEIDA, Paulo R.: La diplomatie de Lula (20032010): une analyse des résultats. In: ROLLAND, Denis; LESSA, Antonio Carlos (Coord.). Relations internationales du Brésil: les chemins de la puissance. Paris: L'Harmattan, 2010. v. 1, p. 249-259. Available at: <http://diplomatizzando.blogspot.com/2010/10/relations-internationales-du-bresil.html>.

ALMEIDA, Paulo R. Lula's foreign policy: regional and global strategies. In: BAER, Werner; LOVE, Joseph (Ed.). Brazil under Lula. New York: Palgrave-Macmillan, 2009. p. 167-183. Available at: < http://www.pralmeida. org/05DocsPRA/1811BrForPolicyPalgrave2009.pdf>

ALMEIDA, Paulo Roberto de. Formação da diplomacia econômica no Brasil: as relações econômicas internacionais no Império. 2. ed. São Paulo: Senac-SP, 2005.

ALMEIDA, Paulo Roberto de. Mercosul: fundamentos e perspectivas. São Paulo: LTr, 1998.

ALMEIDA, Paulo Roberto de. Relações internacionais e politica externa do Brasil: a diplomacia brasileira no contexto da globalização. Rio de Janeiro: LTC, 2012.

AZEVEDO, Roberto. O novo guardião do livre mercado. Veja, n. 2322, May 22, 2013.

BERGSMAN, Joel. Brazil: industrialization and trade policies. London: Oxford University Press, 1970.

BETHELL, Leslie. The independence of Brazil. In: BETHELL, L. (Ed.). Cambridge history of Latin America. Cambridge: Cambridge University Press, 1985. v. 3.

BAER, Werner. The brazilian economy: growth and development. 6. ed. Lynne Rienner, 2007. 
CLEMENS, Michael; WILLIAMSON, Jeffrey. A tariffgrowth paradox?: protection's impact the world around, 1875-1997. NBER Working Paper, Local, n. 8459, 2001. Annex: Import duties over imports, 35 countries, 1865 1950. Available at: <http://www.nber.org/papers/ w8459>. Access: May 2, 2013.

CLEMENS, Michael; WILLIAMSON, Jeffrey; BLATTMAN, Christopher. Who protected and why?: tariffs the world around 1870-1938. Harvard Institute of Economic Research, Discussion Paper n. 2010, jun. 2003 (available at: <http://post.economics.harvard.edu/ hier/2003papers/ 2003list.html>. Access: May 2, 2013.

FARIAS, Rogerio de Souza. Industriais, economistas e diplomatas: o Brasil e as negociações comerciais multilaterais, 19461967. 2012. Dissertation (Ph.D.) - Institute of International Relations, University of Brasilia, Brasilia, 2012.

FRANCO, Gustavo. O plano real e outros ensaios. Rio de Janeiro: Francisco Alves, 1995.

LEITÃO, Miriam. Saga: a luta do povo brasileiro em defesa da sua moeda. Rio de Janeiro: Record, 2011.

PRADO, Maria Clara R. M. do. A real bistória do Real: uma radiografia da moeda que mudou o Brasil. Rio de Janeiro: Record, 2005.

RICUPERO, Rubens. A maior mudança da política externa. Política externa, v. 21, n. 3, p. 95-100, jan./mar. 2013.

TOPIK, Steven. Political economy of the Brazilian State, 1889-1930. Austin: University of Texas Press, 1987.

VENÂNCIO FILHO, Alberto. A intervenção do estado no domínio econômico: o direito público econômico no Brasil. Rio de Janeiro: Fundação Getúlio Vargas, 1968.

VILLELA, Annibal Villanova; SUZIGAN, Wilson. Politica do governo e crescimento da economia brasileira, 18891945. 2. ed. Rio de Janeiro: IPEA-INPES, 1975.

WILCKEN, Patrick, Empire adrift: the portuguese court in Rio de Janeiro, 1808-1821. London: Bloomsbury, 2005. 
Para publicar na Revista de Direito Internacional, acesse o endereço eletrônico www.rdi.uniceub.br ou www.brazilianjournal.org.

Observe as normas de publicação, para facilitar e agilizar o trabalho de edição. 